Інженери В.В. Перестюк, Т. Шуба, В. Чистяк (Tines S.A., м. Краків, Польща),

о-р техн. наук А.А. Плугін (УкрДАЗТ)

V.V. Perestiuk, T. Shuba, V.A. Chystiak, A.A. Plugin

\title{
ОГЛЯД КОНСТРУКТИВНИХ ОСОБЛИВОСТЕЙ ТА УМОВ ЕКСПЛУАТАЦЇ̈ ЗАЛІЗОБЕТОННИХ КОНСТРУКЦІЙ ПІДРЕЙКОВИХ ОСНОВ ЗАЛІЗНИЦЬ
}

\section{OVERVIEW OF DESIGN FEATURES AND OPERATING CONDITIONS REINFORCED CONCRETE UNDER RAIL FOUNDATIONS RAILWAYS}

\begin{abstract}
Актуальність теми і постановка проблеми. На електрифікованих ділянках залізниць, у метрополітенах, трамвайних коліях, конструкції мостів, тунелів, підрейкових основ, інших конструкцій дуже інтенсивно пошкоджуються електрокорозією від дії струмів витоку та блукаючих струмів [1]. Під час руху поїздів виникають значна вібрація та шум. Згідно iз сучасною тенденцією підвищення швидкості руху вібрація та шум також збільшуються. Вібрація та шум, як відомо, несприятливо впливають на людину, довкілля, будівельні конструкції та споруди. Отже, на сьогодні дуже актуально стоїть завдання зниження струмів витоку, шуму та вібрації, особливо у населених пунктах.
\end{abstract}

Електрокорозія, вібрація та шум у значній мірі обумовлені недосконалістю традиційної конструкції верхньої будови колії, яка складається із рейок та підрейкової основи (шпал, плит тощо). Такі конструкції, як правило, жорсткі, добре передають вібрацію та створюють шум, швидко втрачають електроізоляційні властивості. На сьогоднішній день на залізницях України і багатьох інших країн завершується заміна дерев'яних шпал, брусів, поперечин на залізобетонні підрейкові ониови. Найьш розповсюдженою 3 таких основ, що застосовується на відкритих ділянках залізниць, на залізобетонних мостах, у тунелях, є залізобетонні шпали і бруси, які укладаються на щебеневий баласт [2]. Лише на металевих мостах як типова конструкція застосовується безбаластне мостове полотно із залізобетонних плит.

При всіх перевагах залізобетонних підрейкових основ над дерев'яними вони мають i недоліки, серед яких часто недостатні електричний опір i електрокорозійна стійкість [1], неприпустимі в населених пунктах шум та вібрація, які утворюються при проходженні поїздів [3]. Резерви удосконалення конструкції колії на залізобетонних шпалах і щебеневому баласті практично вичерпані, отже, подальшого збільшення електричного опору i електрокорозійної стійкості, зниження шуму та вібрації доцільно досягати шляхом застосування та удосконалення інших конструкцій верхньої будови колії. Найбільш перспективною конструкцією для цього здається суцільна залізобетонна підрейкова основа, яка виконується блочною (збірною) або монолітною. Така конструкція може бути виконана практично повністю водонепроникною, а отже, чинити високий опір струмам витоку i бути 
електрокорозійно стійкою, а також характеризується значними масою та інерцією, які сприяють гасінню шуму та вібрації.

Отже, аналіз конструктивних особливостей залізобетонних підрейкових основ залізниць 3 метою їх подальшого удосконалення, збільшення електричного опору та електрокорозійної стійкості і зниження шуму та вібрації $\epsilon$ актуальним завданням.

Блочні (збірні) підрейкові основи. Перші конструкції колії на бетонній основі з'явились на початку XX сторіччя. Перша колія без баластового шару i шпал довжиною 98 м була побудована інженером Н.С. Долговим у 1909 р. на ст. Пологи Придніпровської залізниці. У 1946 р. у ЦНІІ МШС СРСР під керівництвом Б.I. Мушкатина і Є.M. Бромберга були створені і укладені на дослідних ділянках ще дві нові конструкції підрейкової основи. У 1956-59 pp. ЦНІІ МШС СРСР і Гіпропромтрансбудом під керівництвом М.Ф. Вериго було розроблено десять варіантів конструкцій залізобетонних підрейкових основ, у т.ч. рамно-лежневі 3 довжиною лежня 4,16 м (рис. 1, $a$ ) і плитні 3 шириною плити 2,6 м і довжиною 6,24 м (рис. 1, б) [1]. a)

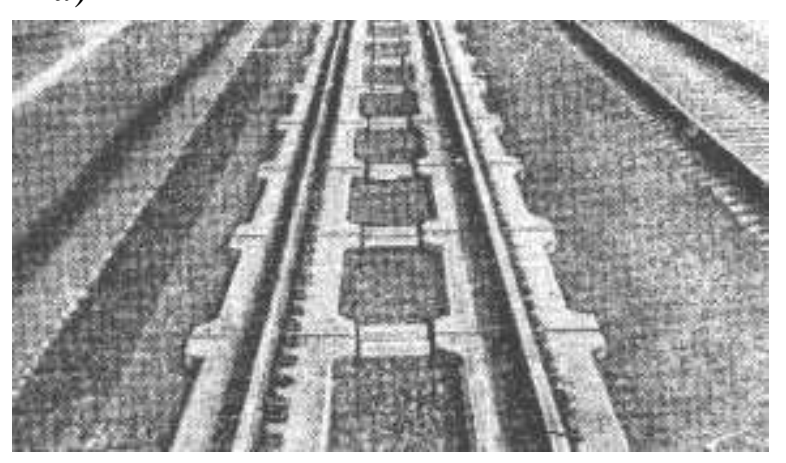

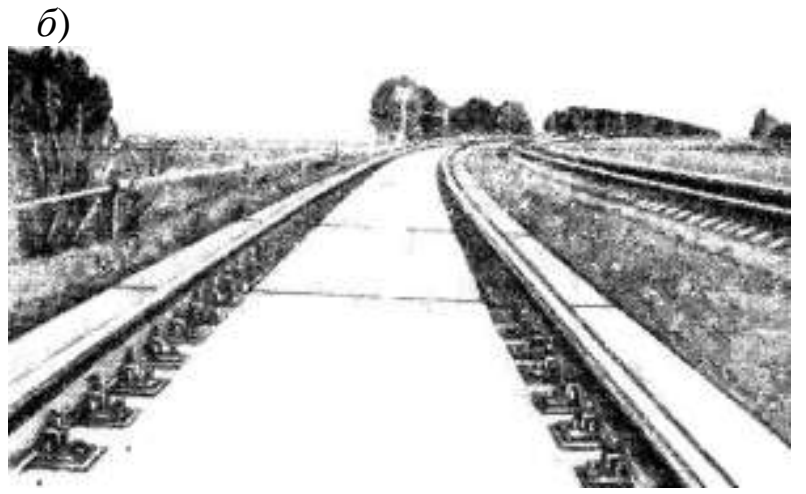

Рис. 1. Блочні підрейкові основи: $a$ - рамно-лежневі; $\sigma$ - плитні

Основні переваги колії на блочній підрейковій основі над традиційною рейкошпальною решіткою обумовлені створенням неперервної опорної площадки для рейкових ниток, що забезпечує високу стабільність рейкової колії як у горизонтальній, так i у вертикальній площинах, усуває нерівномірність деформацій по довжині й ширині колії, запобігає їх швидкому накопиченню, забезпечує зниження витрат на утримання i ремонти колії. На деяких ділянках колії, особливо на штучних спорудах - мостах, естакадах, тунелях, традиційна рейкошпальна решітка виявилась недостатньо раціональною, бо нерівномірні деформації, які накопичуються у коліі, у цих випадках мають особливо неприємні наслідки, а їх усунення і ремонти пов'язані 3 підвищеними складностями внаслідок обмеженого простору i трудністю використання машин і механізмів. Сама ж конструкція штучних споруд забезпечує високу стабільність основи i робить доцільним застосування для колії блочних підрейкових основ.

Починаючи 3 1940-50-х pp., блочні підрейкові основи як рамні, так і плитні пройшли широку експлуатаційну перевірку на залізницях Німеччини, Японії, Франції Чехії, Великобританії, СРСР та ін. Було встановлено, що накопичення остаточних деформацій колії у порівнянні із колією на залізобетонних шпалах зменшується у 23 рази. Суттєво спрощується виконання робіт із поточного утримання колії [1]. 
Однак рамно-лежневі підрейкові основи виявились менш досконалими. Було встановлено, що тиск на основну площадку земляного полотна від них більш високий і нерівномірний, ніж навіть на колії із дерев'яними шпалами, а шарнірність рамно-лежневої конструкції не забезпечувала постійність ширини колії. Тому такі конструкції були визнані неперспективними.

Більш перспективними показали себе конструкції колії з плитними підрейковими основами. Вони виявилась більш надійними i такими, що забезпечують більшу стабільність колії в цілому. Саме плитні основи забезпечують найкращі умови відводу води від конструкції колії, запобігаючи замерзання води в баласті й явища здимання. Однак ці конструкції колії вимагають забезпечення певних достатньо жорстких умов як до якості самої конструкції, так i до іï укладання та експлуатації.

Плити мають опиратися усією нижньою постіллю на підстилаючий шар, ущільнений настільки, щоб працювати лише в пружній стадії. Для найкращої роботи цього шару необхідно, щоб найбільший тиск від рухомого складу через плити передавався по можливості далі від периметра плит, бо опір підстилаючого шару біля країв плит значно менший, ніж під їх середньою частиною [1]. Опорні поверхні для рейок на кожній плиті мають бути строго на одному рівні для забезпечення однакової щільності обпирання рейки по іiі довжині, особливо при нинішньому способі обпирання рейок не безперервно по усій довжині на плиту, а на окремі опори через підкладки або прокладки 3 прогоном між ними (на вітчизняних конструкціях плит відстань між їх осями - 500 мм). Пружність рейкових скріплень повинна бути такою, щоб вона в основному гасила високочастотні вібрації і формувала пружність плитної підрейкової основи в цілому, і щоб при динамічних взаємодіях рухомого складу і колії маса рейки була пружно віддалена від маси плити. Пружність підрейкової основи має бути не лише достатньою, але практично незмінною упродовж року, коливаючись у межах 50-100 МПа. Скріплення повинні забезпечувати постійність і однаковість натягування прикріплювачів для запобігання утворення різкої неоднорідності колії по її довжині, при якій можуть повністю зникнути усі переваги колії на плитній основі. Плитні підрейкові основи можна укладати лише на здорове земляне полотно. Товщина щебеневого шару під плитами має бути достатньою для виконання робіт із його підпресування 3 одночасною вібрацією, що створює найбільш щільне розміщення щебеню усередині шару [1].

Монолітні підрейкові основи. Монолітна бетонна підрейкова основа вперше була укладена у 1926-29 рр. на залізниці Пер-Маркетт у США. Рейкова колія на монолітних основах застосовується, як правило, двох типів: 1 - повністю монолітна, на якій рейки укладаються безпосередньо на плиту, а між підошвою і бетоном укладаються пружні прокладки; 2 - збірно-монолітна, де у монолітну основу замуровуються шпали (або півшпалки), на які встановлюються рейки на скріпленнях. Друга конструкція застосовується в туннелях, у першу чергу метрополітенів (рис. 2). На рис. 2, $a$ показаний переріз двоколійного тунелю на ділянці Цюріх - Баден (Швейцарія). Рейки укладені на двоблочні залізобетонні шпали iз металевим зв'язком між блоками. Блоки шпал розміщуються у гніздах залізобетонних плит 6 , розташованих на тонкому шарі бетону 2. Для відведення води є центральний водовідвідний лотік $1 \mathrm{i}$ бокові водовідвідні лотки 4 , боковими стінками для яких служать стінки каналів 5 для укладання кабелів. 
a)

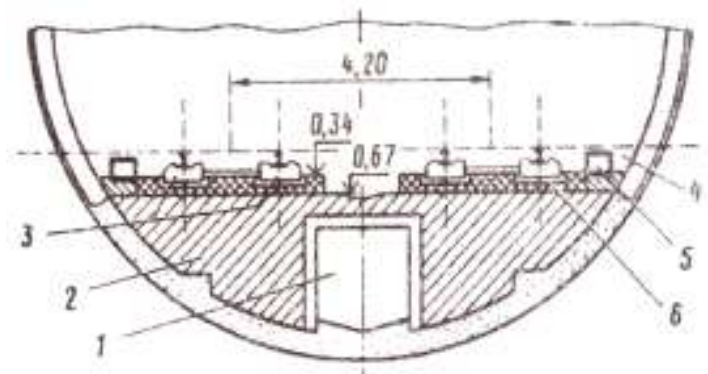

б)

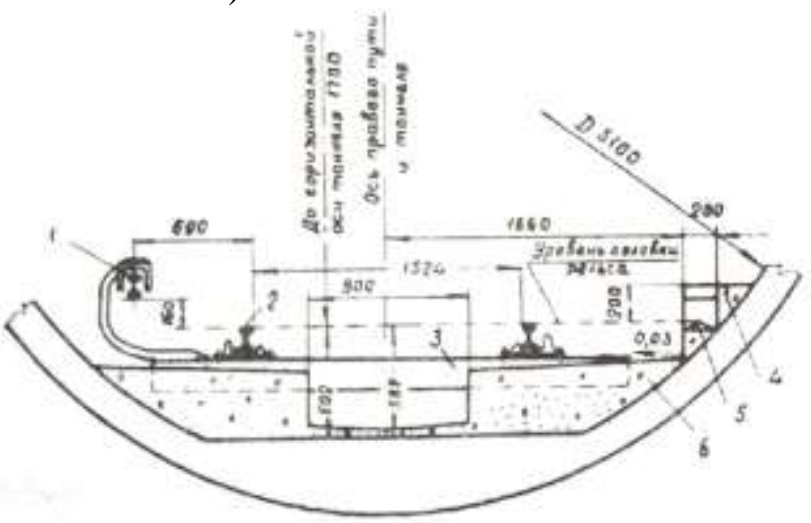

Рис. 2. Монолітні підрейкові основи [1]: $a$ - залізничного тунелю на ділянці Цюрих - Баден (Швейцарія); $\sigma$ - тунелю метрополітену

У метрополітенах (рис. 2, б) залізнична колія $\epsilon$ комбінованою з рейко-шпальною решіткою 2 і бетонною основою 6, в яку замуровані дерев'яні шпали 3 або півшпалки (на станційних коліях). Відмінною особливістю улаштування колії в метрополітенах, яка може визначати електрокорозійну небезпеку, $\epsilon$ наявність окрім колійних рейок 2 третьої (контактної) рейки 1, по якій для споживання двигунів вагонів подається електричний струм високої напруги [1].

a)

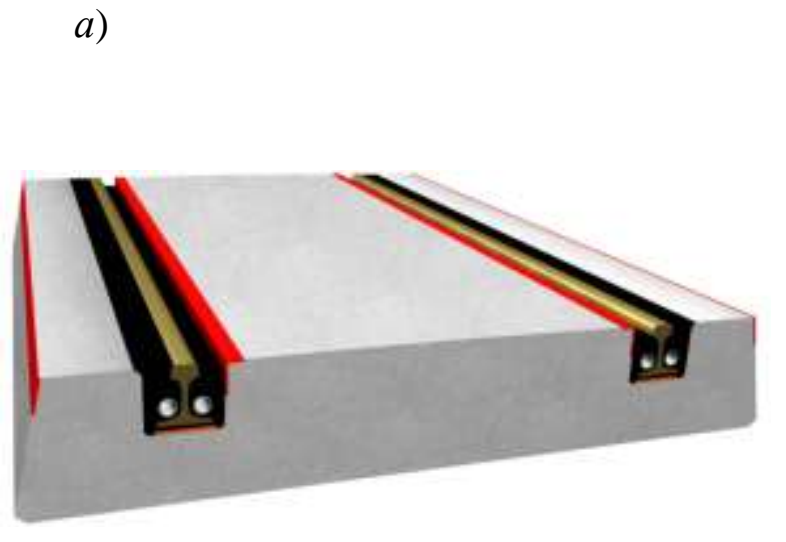

Сучасні збірні і монолітні підрейкові основи, аналіз їх конструктивних особливостей та умов експлуатації. В результаті подальшого удосконалення монолітних збірних i монолітних конструкцій підрейкових основ у XXI ст. на закордонних залізницях, зокрема фірмою Tines у Польщі, впроваджуються системи, наведені на рис. 3 [3]. Їх особливістю $\epsilon$ ізоляція рейки (рис. $3, a$ ) або підрейкової блочної опори (рис. 3, б) за допомогою вібро- та електроізоляційних прокладок знизу та мастики - $з$ боків.

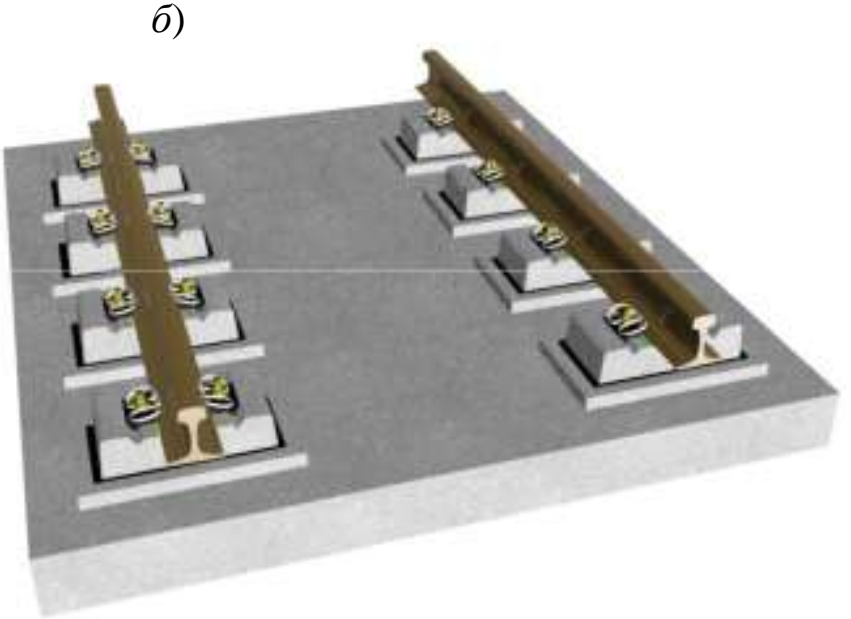

Рис. 3. Сучасні залізобетонні підрейкові основи: $a$ - збірна (для залізничних переїздів) або монолітна (для трамвайних колій) з вібро- та електроізольованою рейкою, укладеною у жолоб; $\sigma$ - збірно-монолітна на вібро- та електроізольованих блочних опорах 
Ці конструкції забезпечують високі міцність і стійкість конструкцій полотна, стабільність положення рейок у процесі експлуатації i незмінну ширину колії, виключають вертикальну та горизонтальну нерівність колії і поздовжнє переміщення рейкових ниток. Це у свою чергу сприяє підвищенню безпеки руху поїздів, особливо при високих швидкостях. Ці конструкції дозволяють також зменшити будівельну висоту і вагу конструкції колії в порівнянні з іншими безбаластними системами, і отже,

a)

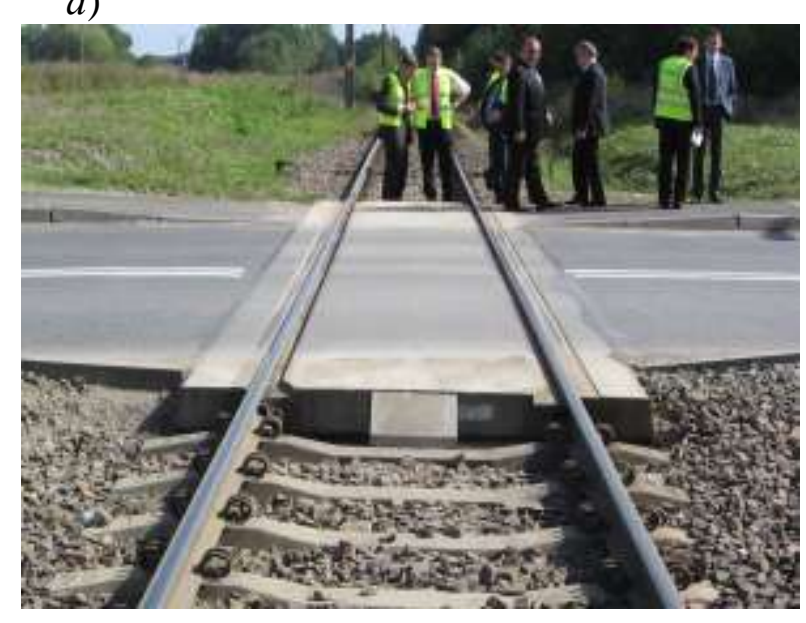

висоту несучої конструкції моста або габаритів тунелю.

Підрейкові основи 3 ізольованою рейкою застосовується переважно на залізничних переїздах (рис. $4, a$ ) або трамвайних коліях (рис. 4, б), оскільки дає можливість забезпечити інтегроване залізнично-автодорожне (трамвайноавтодорожне) полотно. Підрейкова основа 3 ізольованою в жолобі рейкою додатково підвищує безпеку руху поїздів за рахунок збереження цілісності рейкової колії навіть при утворенні в рейці тріщини.

б)

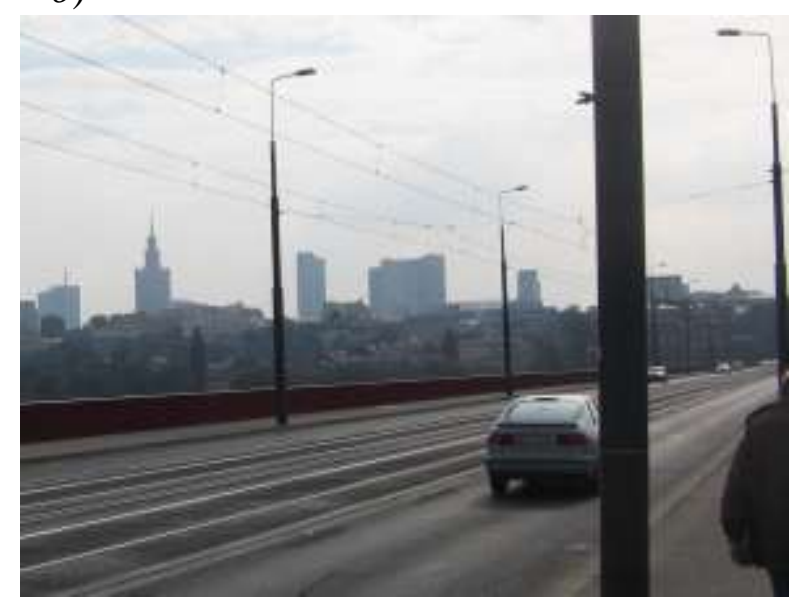

Рис. 4. Залізобетонні підрейкові основи з ізольованою рейкою, укладеною в жолоб: $a$ - збірна на залізничному переїзді (Польща); $\sigma$ - монолітна на трамвайних коліях (м. Варшава, Польща)

Застосування збірних конструкцій дозволяє скорочувати тривалість проведення робіт, зменшувати витрати, пов'язані з тимчасовим припиненням руху. Скорочення часу проведення робіт набуває особливого значення у разі улаштування або перевлаштування переїздів, яке створює незручності як для залізничного, так i для автомобільного руху. Улаштування такого переїзду вимагає мінімальної кількості часу для монтажу та припинення руху за рахунок застосування великогабаритних збірних плит, довжина яких підбирається залежно від довжини переїзду та їх простого i швидкого монтажу. При монтажі залізничного переїзду за даною системою в деяких випадках можна обмежитися припиненням руху всього на одну ніч. Регулювання положення рейки у вертикальній i горизонтальній площині (3 точністю до $1 \mathrm{Mм)}$ перед заливкою мастикою здійснюється за допомогою прокладок різної товщини i клинів. Аналогічним чином прискорюється і монтаж прогонових будов, виготовлених 3 підрейковою основою поза будівельним майданчиком.

Підрейкові основи 3 ізольованими блочними опорами застосовуються переважно в залізничних тунелях і тунелях 


\section{Обрані праці 4-ї Міжнародної науково-технічної конференції}

метрополітенів. Так, Варшавський залізничний вузол у Польщі містить декілька тунелів. По мірі реконструкції діаметрального тунелю в ньому улаштовуються виключно підрейкові основи на ізольованих блочних опорах (рис. 5, a). При будівництві тунелю нової лінії до Варшавського аеропорту також улаштовані підрейкові основи на ізольованих блочних опорах (рис. 5, б). Останніми роками всі нові ділянки Варшавського метрополітену будуються 3 підрейковими основами на ізольованих блочних опорах (рис. 6).

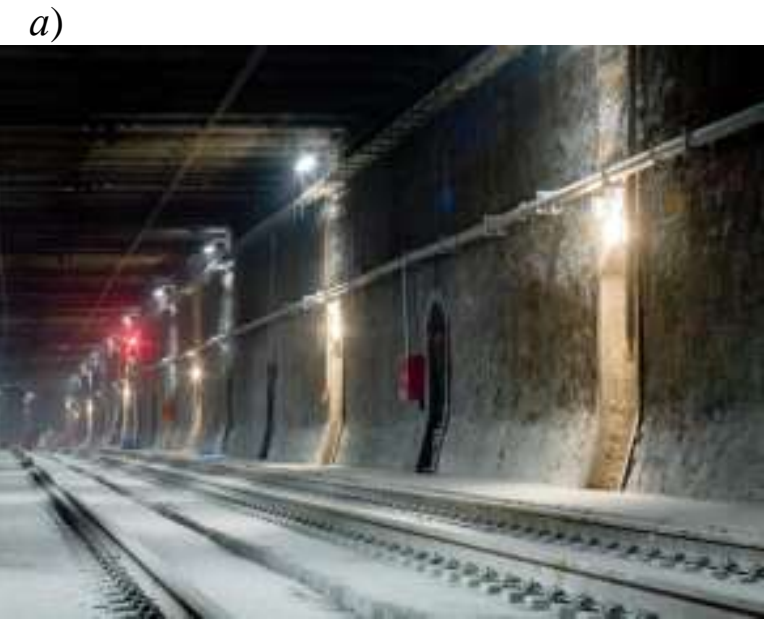

б)

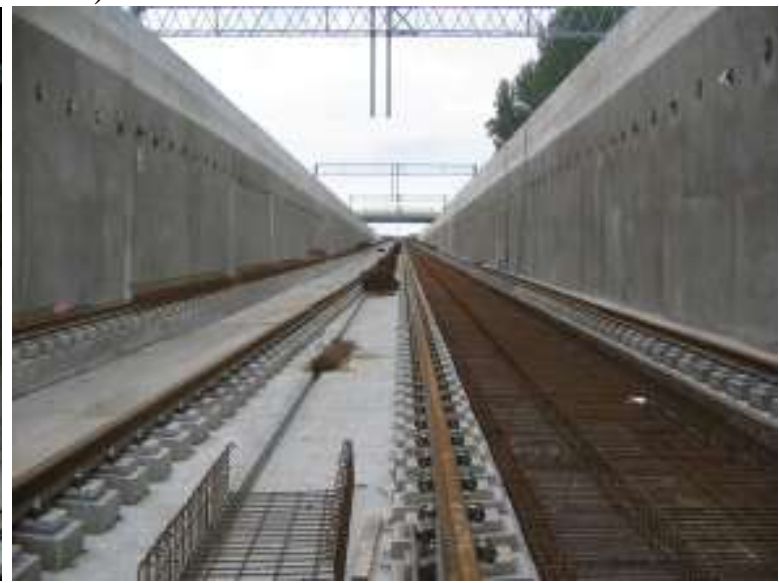

Рис. 5. Збірно-монолітні залізобетонні підрейкові основи з ізольованими блочними опорами

в тунелях Варшавського залізничного вузла: $a$ - діаметральний тунель, лінія № 448;

б - виїмка на підході до тунелю нової лінії до Варшавського аеропорту

a)

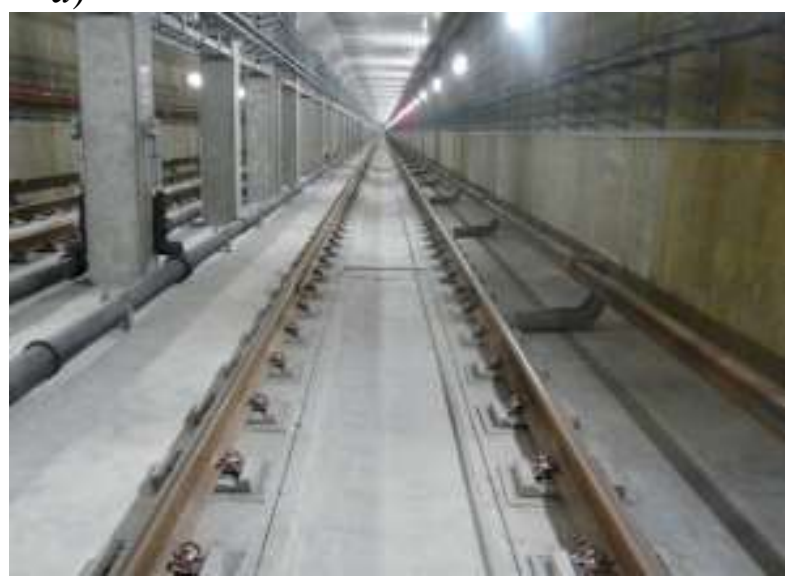

б)

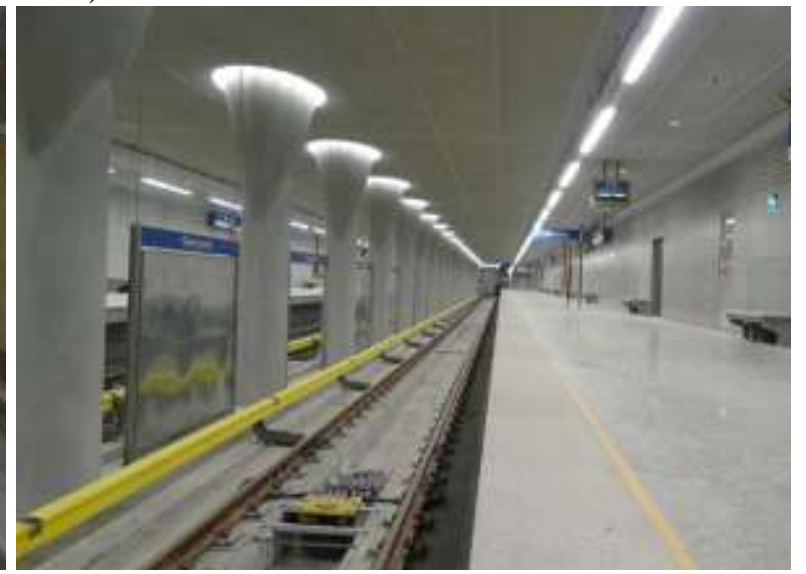

Рис. 6. Збірно-монолітні залізобетонні підрейкові основи з ізольованими блочними опорами в тунелях Варшавського метрополітену: $a$ - перегінний тунель відрізку В 21 і В 22; б- станційний тунель станції А 21 і А 22

32010 p. підрейкові основи на ізольованих блочних опорах впроваджуються і в Україні. В Київському метрополітені на 1-й колії Куренівсько-
Красноармійської лінії 15.12 .2010 була прийнята в експлуатацію експериментальна ділянка довжиною 200 м на ізольованих блочних опорах EBS виробництва фірми 
Tines (Польща, рис. 7). За результатами експлуатації цієї ділянки було улаштовано

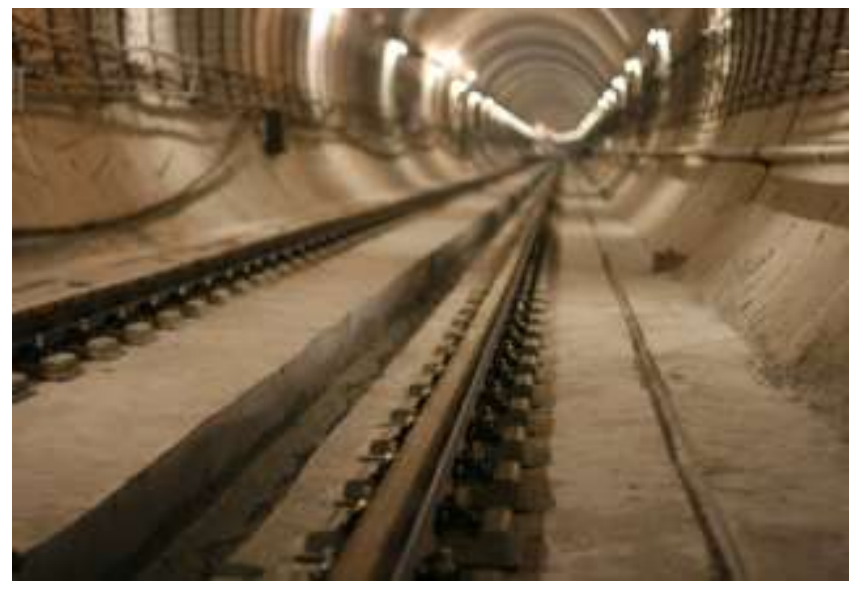

такі ж підрейкові основи на нових станціях - Виставковий центр та Іподром (рис. 8).
Рис. 7. Експериментальна ділянка на ізольованих блочних опорах $\mathrm{EBS}$ виробництва фірми Tines (Польща) на 1-й колії Куренівсько-Красноармійської лінії Київського метрополітену a)

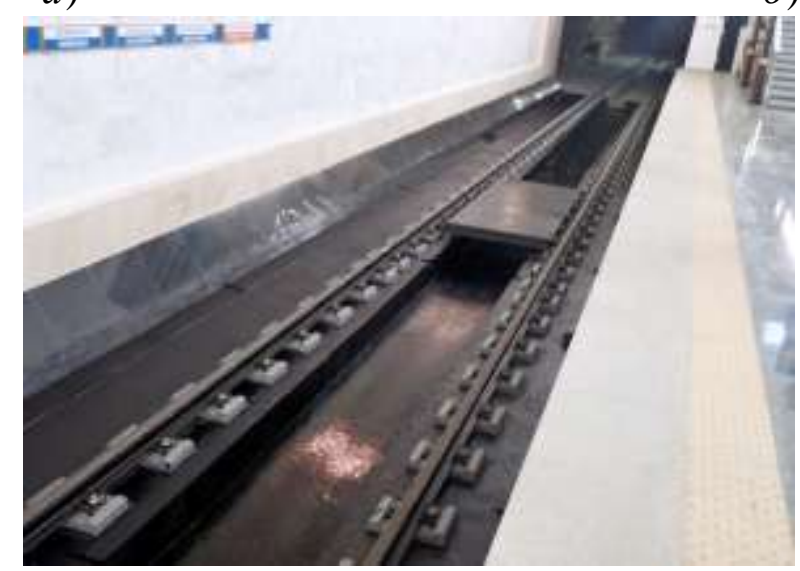

б)

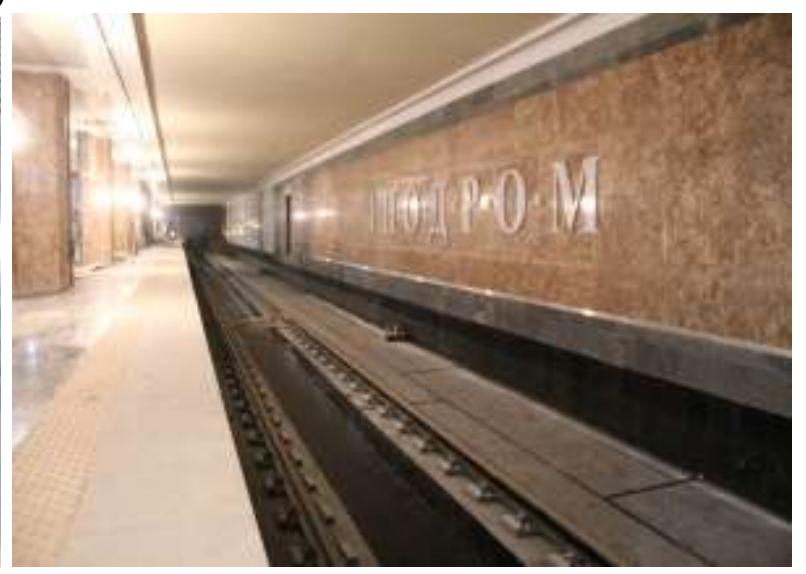

Рис. 8. Збірно-монолітні залізобетонні підрейкові основи з ізольованими блочними опорами в станційних тунелях Київського метрополітену: $a$ - ст. Виставковий центр; $\sigma-$ ст. Іподром

В збірно-монолітній підрейковій основі $з$ ізольованими блочними опорами рейки прикріплюються не до плити або шпал, а до окремих блочних опор, закріплених у готових зовнішніх залізобетонних або полімеркомпозиційних стаканах через еластичні прокладку i двокомпонентну мастику (рис. 9) [3, 4]. Зовнішні стакани при улаштуванні рейкового полотна замуровуються в монолітну залізобетонну плиту (рис. 9).

Така конструкція у порівнянні 3 рейко-шпальною решіткою на баласті забезпечує більш рівномірний розподіл навантаження від рухомого складу і гасіння коливань, обумовлених його рухом. Залізобетонний блок 3 еластичними прокладкою i мастикою та пружним проміжним рейковим скріпленням забезпечують відповідність колії всім вимогам до міцності, жорсткості, пружності. Значна маса залізобетонних блоків забезпечує низький коефіцієнт динамічної жорсткості, що сприятливо впливає на розподілення вертикального i горизонтального тиску від коліс, 
зменшуючи хвилеподібне зношування рейок. У цій системі існує можливість пристосування статичної і динамічної жорсткостей до локальних експлуатаційних умов шляхом підбору характеристик прокладки і заливної мастики.

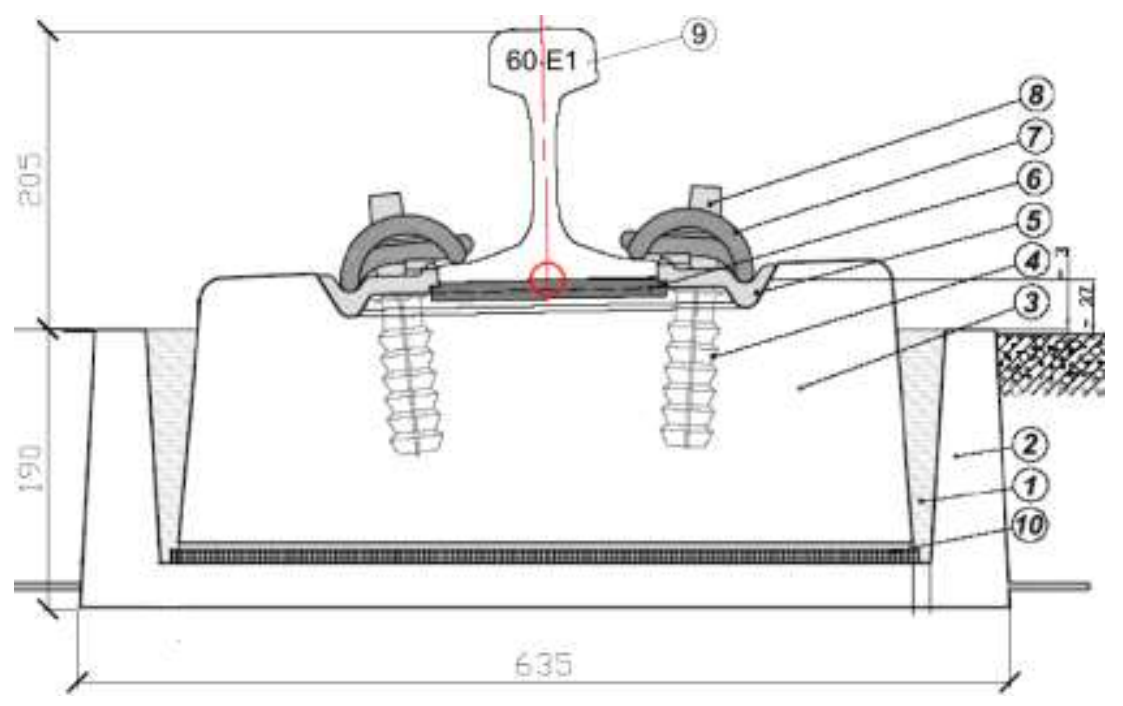

Рис. 9. Ізольована блочна опора $з$ проміжним рейковим скріпленням Vossloh в складанні: 1 - заливна еластична мастика; 2 - зовнішній залізобетонний стакан; 3 - залізобетонний опорний блок; 4-8 - деталі скріплення Vossloh; 9 - рейка; 10 - еластична прокладка
Застосування збірно-монолітних конструкцій у порівнянні 3 монолітними дозволяє скорочувати тривалість проведення робіт за рахунок швидкого i нескладного монтажу блочних опор одразу у проектне положення за допомогою кондукторів та їх обетонування.

Основні переваги залізничного полотна на блочних опорах: стійкість 3'єднання опори до дії вологи, морозу i корозії; ефективне гасіння коливань; можливість підбору ступеня гасіння коливань залежно від локальних умов; простий монтаж колії; проста конструкція і технологія виконання бетонного фундаменту; ефективна електрична ізоляція рейок; вільний доступ до рейок і скріплень; невелика будівельна висота конструкції 3 фундаментом; мінімальні витрати на експлуатацію.

\section{Висновки та рекомендації}

1. $\mathrm{y}$ наш час на залізницях i трамвайних лініях, в метрополітенах активно впроваджуються нові конструкції залізобетонних збірних, збірно-монолітних і монолітних підрейкових основ 3 вібро- та електроізольованими блочними опорами або рейками.
2. Переваги цих конструкцій над традиційними рейко-шпальною решіткою на баласті і тощо:

- високі міцність і стійкість конструкцій полотна, стабільність положення рейок i колії в процесі експлуатації, виключення вертикальної та горизонтальної нерівності колії і поздовжнє переміщення рейкових ниток, більш рівномірний розподіл навантаження від рухомого складу і гасіння коливань від нього, зменшення зносу рейок, у т.ч. хвилеподібного, що сприяє підвищенню безпеки руху поїздів, особливо при високих швидкостях;

- можливість пристосування статичної і динамічної жорсткостей колії, здатності гасіння коливань до локальних експлуатаційних умов шляхом підбору характеристик прокладок і заливної мастики;

- стійкість до дії вологи, морозу, корозії, електрокорозіі, ефективна електрична ізоляція рейок;

- зменшена будівельна висота і вага конструкції колії в порівнянні навіть 3 іншими безбаластними системами, і отже, висота несучої конструкції моста або габаритів тунелю; 
- скорочення тривалості проведення робіт, наприклад, при улаштуванні залізничних переїздів із великогабаритних збірних плит або при улаштування колії на блочних опорах за рахунок їх швидкого i нескладного монтажу одразу у проектне положення за допомогою кондукторів та обетонування.

3. Виходячи із переваг визначені галузі застосування збірно-монолітного безбаластного залізничного полотна на блочних опорах:

- мости, тунелі;
- станційні колії, перегінні колії, стрілочні переводи і глухі перехрестя в межах населених пунктів;

- колії на прямих і кривих ділянках радіусом 160 м та більше;

- можливість монтажу контррейок, напрямних;

- різні системи кріплення;

- рейки будь-якого профілю;

- максимальний тиск на вісь 245 кН;

- максимальна швидкість залізничних транспортних засобів 250 км/год.

\section{Список літератури}

1. Даніленко, E.I. Залізнична колія. Улаштування, проектування i розрахунки, взаємодія з рухомим складом [Текст]: підручник для ВНЗ у 2 т. / Е.І. Даниленко. - К.: Інпрес, 2010. - T. 1. -528 c.

2. Электрокоррозия железобетонных мостов и других искусственных сооружений [Текст] / А.Н. Плугин, А.А. Скорик, А.А. Плугин и др. // Залізничний транспорт України. 2004. - № 1. - С. 11-13.

3. Вуйчак, И. Современные конструкции безбалластного полотна как решение эксплуатационных проблем рельсовых дорог [Текст] / И. Вуйчак // Проблеми надійності та довговічності інженерних споруд та будівель на залізничному транспорті // Зб. наук. праць. Харків: УкрДАЗТ, 2009. - Вип. 109. - С. 93-113.

4. Tines s.r. Офіційний сайт / www.tines.com.ua.

Ключові слова: підрейкова основа, залізобетон, віброізоляція, шумоізоляція, електричний опір.

\section{Анотаціiі}

Проведений аналіз конструктивних особливостей залізобетонних підрейкових основ залізниць 3 метою їх подальшого удосконалення, у т.ч. збільшення електричного опору та електрокорозійної стійкості, зниження шуму та вібрації. Найбільш перспективною для цього визнана суцільна залізобетонна підрейкова основа, яка виконується блочною (збірною), монолітною, збірно-монолітною. Показані переваги та недоліки цих конструкцій, визначені шляхи з подальшого покращення їх характеристик.

Проведен анализ конструктивных особенностей железобетонных подрельсовых оснований железных дорог с целью их дальнейшего усовершенствования, в т. ч. увеличения электрического сопротивления и электрокоррозионной стойкости, снижения шума и вибрации. Наиболее перспективной для этого признано сплошное железобетонное подрельсовое основание, выполняемое блочным (сборным), монолитным, сборномонолитным. Показаны преимущества и недостатки этих конструкций, определены пути дальнейшего улучшения их характеристик. 
The analysis of structural features under rail concrete foundations railways for further improvement, including increase in electrical resistance and electro corrosive stability, lower noise and vibration. The most promising for this under rail recognized solid concrete foundation block is executed, monolithic, precast-monolithic. The advantages and disadvantages of these designs, the ways to further improve their performance. 